\title{
IMPLEMENTATION OF ENERGY EFFICIENCY PROJECTS IN LATVIA'S HOUSING STOCK AND ITS INFLUENCE ON THE CONSTRUCTION INDUSTRY
}

\author{
Aleksandrs Sakovskis \\ Baltic International Academy, Latvia
}

\begin{abstract}
Development of the housing and utilities sector for provision of necessary living conditions is one of the most significant areas in the national socio-economic transformation. Residential construction, housing services and public utilities, that ensure regeneration and maintenance of housing stock and bring housing and utilities to their direct consumers, are the key industries of the sector. The development of the housing sector in Latvia fails to meet the EU requirements: tasks placed on the sector are not carried out properly thus significantly lowering quality of life of the population. Therefore, the issue of housing and utilities stands to be one of the most pressing social problems in the country. The housing and utilities sector suffers from substantial difficulties due to lack of financing, weak physical infrastructure, an insufficient number of skilled personnel, lack of a forethought housing and utilities policy, and inadequately developed regulations for companies operating within the area of housing services maintenance. To the author, the key issue of the housing services in Latvia is renovation of obsolete housing stock. In the presented scientific paper, based on studies of the economic effect from the implementation and development of energy efficiency projects (renovation) of multi-apartment buildings in Latvia, an analysis is performed of the influence of renovation projects on the construction industry in Latvia. Therefore, the aim of the research is to examine the potential of the energy efficiency (renovation) projects of multi-apartment buildings in Latvia as a tool for development of the construction industry and of the economy of the country in general.

Econometric methods as well as methods of sociological research and statistical analysis are applied in this work. In the final part, the author demonstrates that the programmes for raising the energy efficiency of housing stock are an effective tool for development of the construction industry in Latvia.
\end{abstract}

Keywords: construction industry, energy efficiency, housing stock, renovation, Latvia.

\section{Introduction}

The state of the housing stock and housing and utility sector of Latvia has lately been drawing attention of both the government and the expert community. One of the main issues on the agenda is energy efficiency of multi-apartment buildings (MABs) and the infrastructure ensuring operations of residential as well as social and industrial buildings. The author applies the term "renovation" for describing the housing stock energy efficiency programmes. Econometric 
Sakovskis, 2018. Implementation of Energy Efficiency Projects in Latvia's Housing Stock and its Influence on the Construction Industry

methods were applied for assessing the influence of the renovation programme of Latvia's housing stock on the construction industry. In the final part of the paper, the housing stock energy efficiency programmes are demonstrated to have a recovery effect on the construction industry as such and the economy in general.

The aim of the research is to examine the potential of the energy efficiency (renovation) projects of multi-apartment buildings in Latvia as a tool for development of the construction industry in Latvia.

The research applies econometric methods, methods of statistical analysis and sociological research.

\section{Main results of theory and practice}

The housing and utilities sector has a significant place in the national economy, largely defining social, economic and technical tasks for shaping the daily living environment, ensuring safe and favourable housing and living conditions. Housing and utilities is one of the most significant sectors and its development has a direct impact on the quality of life. Therefore, nowadays, among the focus areas are favourable conditions for development of housing and utilities services, support of innovative technologies and ideas aimed at sustainable allocation of vital natural resources, growth of financial support for modernization, renovation and construction of housing stock and objects of community infrastructure. Among the researchers focusing on the management of housing and utilities is V. Gassul (Gassul, 2018). He examines the structure of the municipal housing economy and offers ways of its reorganization in the Russian Federation. John C. Macih in his monograph "Preventative Maintenance for Multi-Family Housing: For Apartment Communities, Condominium Associations and Town Home Developments" explores interoperability of the structures engaged in maintenance of multi-apartment buildings (Macih, 2005). The authors mainly explore the issues related to the management of multi-apartment buildings and development of interconnected structures for delivering maintenance of multi-apartment buildings. In this paper, it is suggested to consider the housing and utilities sector as a tool of economic recovery and improvement of quality of life for the nation.

Renovation is a current trend not only for Latvia but for Europe in general. Initiatives for housing stock insulation stem from the common EU energy efficiency policies that are being substantially financed. Renovation offers a complex solution to the main problems: insulation of outer walls, upper storeys, basements, semi-basement floors, replacement of doors and windows in the shared space, renovation of general utilities, installation of modern metering devices, etc. This allows renovating buildings both inside and outside (renovated buildings look as newly built structures) and significantly save on costs for 
utilities, especially heating. Heating is around 32-62 \% cheaper for the apartments in the renovated buildings (Sakovskis \& Chekalin, 2017). Hot water bills are also significantly smaller.

In comparison with the developed countries of Europe, Latvia demonstrates low quality of housing conditions as the period of service of most of the residential buildings is substantial, but the technical state and consumer scope are far from the current requirements (Sakovskis \& Chekalin, 2017). For instance, thermal capacity of the majority of the buildings is insufficient. More than half of the buildings (58\%) were built before 1940, and $26.5 \%$ of the buildings were built in 1941-1980. These require renovation (capital repair). Since $71 \%$ of the population lives in the buildings built during 1941-1990, direct attention must be drawn to the time-frame and quality of renovation and construction works as well as housing insulation activities (LR Labklajibas Ministrija, 2011).

According to the data of the Central Statistical Bureau of Latvia for 2015, an average living floor space per one resident is $38 \mathrm{~m}^{2}$. Therefore, as presented in Table 1 , around $72 \%$ of the population in Latvia live in serial multi-apartment buildings.

Table 1 Breakdown of residential buildings in Latvia by type, 2014 (source: The Ministry of Economics of Latvia)

\begin{tabular}{|c|c|c|}
\hline Building type & Number, thousand pcs & Floor space, million $\mathbf{m}^{2}$ \\
\hline $\begin{array}{l}\text { One- or two-bedroom apartment } \\
\text { buildings }\end{array}$ & 313 & 32 \\
\hline $\begin{array}{l}\text { Multi-apartment building with } \\
10 \text { and more apartments }\end{array}$ & 39 & 55 \\
\hline TOTAL & 352 & 87 \\
\hline
\end{tabular}

Therefore, the standard-design MABs built during the Soviet era that account for more than $80 \%$ of all the standard MABs are of particular research interest. There are 39.1 thousand MABs in Latvia, while in Riga, there are 11.9 thousand buildings comprising almost $30 \%$ of the total residential housing and accommodating half of Latvia's population.

In their 2015 research, the Institute of the Civil Engineering and Real Estate Economics at RTU in cooperation with the Latvian Real Estate Association (LANIDA) indicate that according to the State Land Service of Latvia there were only 2164 MABs built during 1992-2014 (only six percent of the total housing stock). At the same time, the useful service life of 3000 MABs ends in 2020-2040, while the useful service life of a number of engineering infrastructure facilities, utility networks in particular, is already complete. 
Sakovskis, 2018. Implementation of Energy Efficiency Projects in Latvia's Housing Stock and its Influence on the Construction Industry

According to the state joint-stock company ALTUM responsible for allocation of the EU funds for the MABs renovation, the state of around 10000 residential houses in Latvia (more than $25 \%$ of the total MABs) is critical. While according to Riga Energy Agency, 6000 MABs are in urgent need of renovation. The total floor space of these is 12 million $\mathrm{m}^{2}$, comprising $20 \%$ of the total housing stock available floor space in the city (Golunovs, 2014).

It is generally obvious that the renewal of Latvia's housing stock is very slow: the market can offer only 0.3 percent of new required housing stock. According to independent experts, significant part of Riga's housing stock is worn out and in need of capital repair, including heating insulation works and change of utility networks. Moreover, the useful life of a number of MABs ends soon, creating a significant safety problem that must be solved at the national level. Therefore, in the author's opinion, there are currently no alternatives to the MABs renovation.

The renovation and energy efficiency of MABs represent a sector that could potentially provide a new life for residential buildings, objects of social infrastructure and industrial buildings, and reanimate the construction industry, manufacturing of modern building materials, provide new jobs in the affiliated accounting, legal and transportation companies. The renovation process brings a dual effect: first, it creates a considerable market for the development of the construction industry and related sectors of the economy; second, it brings savings of energy resources across the country.

Several indicators of already finished projects of MABs renovation are used to demonstrate connection between the financing of renovation projects for the housing stock in Latvia and the main indicators of the construction industry which were available in the database of the Central Statistical Bureau of Latvia: volume of construction, number of the employed and average gross earnings in the construction industry. For testing the assumption, the main indicators are accommodated in two tables: Table 2 and Table 3. Since the statistics of renovation project financing for MABs is available starting from 2010, the other indicators are shown for the period of 2010-2016. According to the data of the Central Statistical Bureau of Latvia, active allocation of the EU funds for energy efficient renovation of housing stock started in 2010 (Table 2).

For further analysis, the author combined into one table the main indicators of the constructions industry in Latvia taken from the data base of the Central Statistical Bureau of Latvia: the volume of construction, the number of the employed in the construction industry and monthly gross earnings in the construction industry. These are presented in Table 3. 
Table 2 EU structural funds allocation for housing stock renovation projects, 2017 (source: The Ministry of Economics of Latvia)

\begin{tabular}{|c|c|c|}
\hline Year & $\begin{array}{c}\text { Number } \\
\text { of projects }\end{array}$ & $\begin{array}{c}\text { Total } \\
\text { investment, EUR }\end{array}$ \\
\hline 2010 & 14 & $1,562,659$ \\
\hline 2011 & 42 & $5,086,750$ \\
\hline 2012 & 87 & $11,910,669$ \\
\hline 2013 & 171 & $32,560,748$ \\
\hline 2014 & 181 & $40,112,412$ \\
\hline 2015 & 170 & $39,273,899$ \\
\hline 2016 & 80 & $20,241,645$ \\
\hline Total & 745 & $150,748,781$ \\
\hline
\end{tabular}

Table 3 Main indicators of the construction industry in Latvia, 2010-2016

(source: The Central Statistical Bureau of Latvia)

\begin{tabular}{|l|c|c|c|c|c|c|c|}
\hline & $\mathbf{2 0 1 0}$ & $\mathbf{2 0 1 1}$ & $\mathbf{2 0 1 2}$ & $\mathbf{2 0 1 3}$ & $\mathbf{2 0 1 4}$ & $\mathbf{2 0 1 5}$ & $\mathbf{2 0 1 6}$ \\
\hline $\begin{array}{l}\text { Volume of } \\
\text { construction, } \\
\text { thousand EUR }\end{array}$ & $1,077,886$ & $1,235,994$ & $1,515,188$ & $1,661,001$ & $1,796,874$ & $1,743,726$ & $1,100,000 *$ \\
\hline $\begin{array}{l}\text { Average } \\
\text { number of the } \\
\text { employed in } \\
\text { the construc- } \\
\text { tion industry }\end{array}$ & 57,000 & 60,875 & 62,350 & 67,275 & 73,250 & 71,900 & 66,400 \\
\hline $\begin{array}{l}\text { Average } \\
\text { monthly gross } \\
\text { earnings in the } \\
\text { construction } \\
\text { industry, EUR }\end{array}$ & 555.75 & 586.25 & 595 & 637.5 & 688.25 & 744 & 747 \\
\hline
\end{tabular}

*Data for 2016 are approximate since the CSB of Latvia provides data for the first 6 months of 2016: $€ 528,894$ thousand.

Further, by applying Pierson's correlation coefficient, a correlation between the number of the employed in the construction industry and the amount of investment and earnings is calculated. Table 4 presents the calculated data.

According to the preformed calculations, a correlation between the number of the employed in the construction industry and the amount of investment in the construction industry is 0.86 , presenting a strong correlation. This reflects the situation: an increase in investment brings an increase of the number employed in the industry.

An average correlation of 0.75 is between the amount of investment and earnings in the industry. Undeniably, the relation is significant, however, other factors also influence the presented indicators. 
Sakovskis, 2018. Implementation of Energy Efficiency Projects in Latvia's Housing Stock and its Influence on the Construction Industry

Table 4 Pierson's correlation between the number of the employed in the construction industry and the amount of investment and earnings in Latvia, 2010-2016

(source: table created by the author based on data of the Central Statistical Bureau of Latvia and the Ministry of Economics of Latvia)

\begin{tabular}{|c|c|c|c|}
\hline Year & $\begin{array}{c}\text { Number } \\
\text { of employed }\end{array}$ & Investment, EUR & $\begin{array}{c}\text { Earnings, } \\
\text { EUR }\end{array}$ \\
\hline 2010 & 57,000 & $1,562,659$ & 555.75 \\
\hline 2011 & 60,875 & $5,086,750$ & 586.25 \\
\hline 2012 & 62,350 & 11910,669 & 595 \\
\hline 2013 & 62,275 & $32,560,748$ & 637.5 \\
\hline 2014 & 73,250 & $40,112,412$ & 688.25 \\
\hline 2015 & 71,900 & $39,273,899$ & 744 \\
\hline 2016 & 66,400 & $20,241,645$ & 747 \\
\hline & Correl & 0.86 & 0.75 \\
\hline
\end{tabular}

The calculations of the coefficient of determination $\mathrm{R}^{2}$ show high dependency of 0.75 between the presented variables. The graph shows high dependency between the indicators.

Further, regression analysis is used for exploring the investment in energy efficiency project impact on the average level of earnings in the industry (Figure 1).

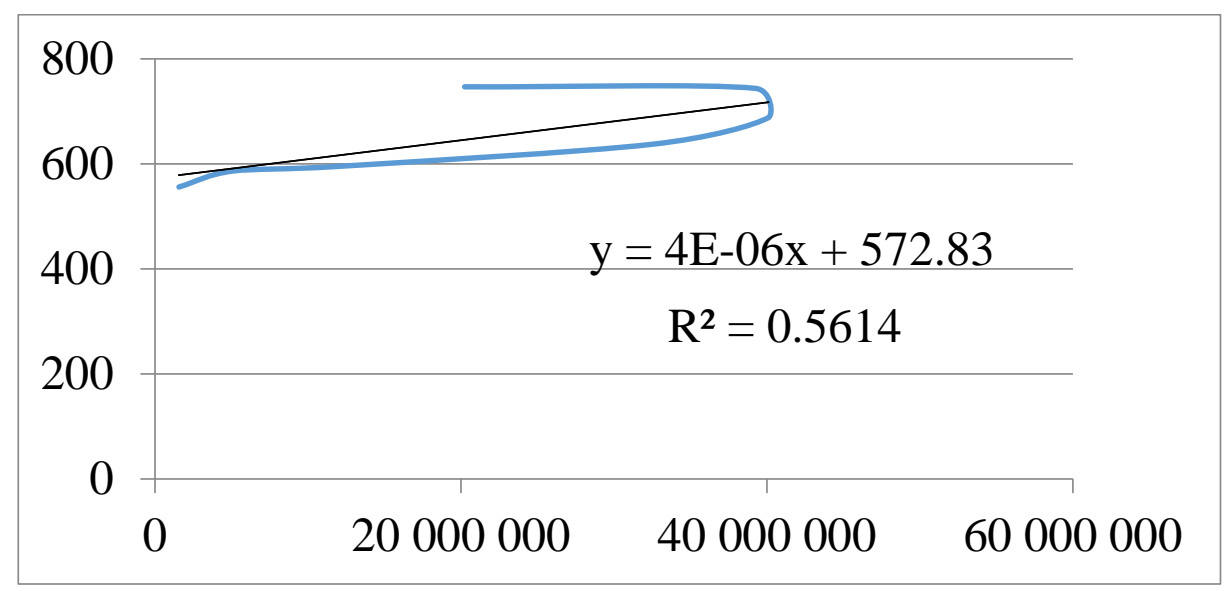

Figure 1. Analysis of the investment impact on average earnings in the industry (source: figure created by the author based on data of the Central Statistical Bureau of Latvia and the Ministry of Economics of Latvia)

The calculations present linear dependency between the earnings level in the industry and the amount of investment in renovation projects for the housing stock 
in Latvia in 2010-2016. The correlation coefficient of 0.56 shows reasonably average interconnection between the presented variables.

A correlation analysis for gross earnings in the construction industry and the amount of investment in the housing stock renovation is presented in Table 5.

Table 5 Correlation of gross earnings in the construction industry and the amount of investment in the housing stock renovation projects

(source: table created by the author based on data of the Central Statistical Bureau of Latvia)

\begin{tabular}{|c|c|c|}
\hline Years & $\begin{array}{c}\text { Amount of investment, } \\
\text { EUR }\end{array}$ & $\begin{array}{c}\text { Industry gross earnings, } \\
\text { EUR }\end{array}$ \\
\hline 2010 & 747 & 555.75 \\
\hline 2011 & $1,235,994$ & 586.25 \\
\hline 2012 & $1,515,188$ & 595 \\
\hline 2013 & $1,661,001$ & 637.5 \\
\hline 2014 & $1,796,874$ & 688.25 \\
\hline 2015 & $1,743,726$ & 744 \\
\hline 2016 & $1,100,000$ & 747 \\
\hline \multicolumn{2}{|c}{} \\
\hline
\end{tabular}

Table 6 Gross domestic product in current prices, the amount of investment in the housing stock renovation projects and the total output of the construction industry in Latvia (source: table created by the author based on data of the Central Statistical Bureau of Latvia and and the Ministry of Economics of Latvia)

\begin{tabular}{|c|c|c|c|c|}
\hline Years & $\begin{array}{c}\text { Amount of } \\
\text { investment in } \\
\text { renovation, } \\
\text { EUR }\end{array}$ & $\begin{array}{c}\text { Output of the } \\
\text { construction } \\
\text { industry, } \\
\text { thousand EUR }\end{array}$ & $\begin{array}{c}\text { GDP, thousand } \\
\text { EUR }\end{array}$ & $\begin{array}{c}\text { Share of } \\
\text { investment in } \\
\text { renovation in the } \\
\text { total output of } \\
\text { the construction } \\
\text { industry }\end{array}$ \\
\hline 2010 & $1,562,659$ & $1,077,886$ & $17,937,881$ & $0.14 \%$ \\
\hline 2011 & $5,086,750$ & $1,235,994$ & $20,302,761$ & $0.41 \%$ \\
\hline 2012 & $11,910,669$ & $1,515,188$ & $21,885,613$ & $0.79 \%$ \\
\hline 2013 & $32,560,748$ & $1,661,001$ & $22,786,588$ & $1.96 \%$ \\
\hline 2014 & $40,112,412$ & $1,796,874$ & $23,618,163$ & $2.23 \%$ \\
\hline 2015 & $39,273,899$ & $1,743,726$ & $24,320,324$ & $2.25 \%$ \\
\hline 2016 & $20,241,645$ & $1,100,000$ & $24,926,688$ & $1.84 \%$ \\
\hline
\end{tabular}

The correlation analysis shows a modest coefficient of 0.52 between gross earnings in the construction industry and the amount of investment during the chosen period. This corresponds to the overall economic situation in the country 
Sakovskis, 2018. Implementation of Energy Efficiency Projects in Latvia's Housing Stock and its Influence on the Construction Industry

in the context of the formation of wages. A considerably high level of a shadow economy exists in the construction industry of Latvia.

Lastly, the correlation between the gross domestic product of Latvia and the investment in the housing stock renovation projects and the total volume of construction is explored in Table 6.

Table 6 provides insight into the share of investment in renovation of the housing stock of Latvia in relation to the total output of the construction industry in current prices. The analysis show that the share is quite low, the highest number being only $2.25 \%$. However, the broader picture is provided in Table 7 by exploring the correlation between the main indicators previously presented in Table 6.

Table 7 The correlation between the amount of investment in renovation and total output of the construction industry, the total output of the construction industry and GDP, the amount of investment in renovation and GDP in Latvia

(source: table created by the author based on data of the Central Statistical Bureau of Latvia and and the Ministry of Economics of Latvia)

Correlation between the amount of investment in renovation and the 0.84012 total volume of construction

\begin{tabular}{|l|l|}
\hline Correlation between the total volume of construction and GDP & 0.50078 \\
\hline
\end{tabular}

\begin{tabular}{|l|l|l|}
\hline Correlation between the amount of investment in renovation and GDP & 0.78832 \\
\hline
\end{tabular}

The calculations show peculiar dependency. While the share of the amount of investment in renovation is quite low in the total output of the construction industry, the correlation coefficient between these indicators is considerably high: 0.84 . This proves that the construction industry's development in Latvia is highly dependent on the implementation of the housing stock renovation projects. While the correlation between the total output of the construction industry and GDP is average, 0.50 , the correlation between the amount of investment in the housing stock renovation and GDP is also quite high: 0.79 . This shows a high impact of implementation of the energy efficiency projects on the economy of the country in general and not only in terms of the construction industry, but in terms of the energy industry too.

\section{Conclusions}

The performed econometric analysis of the influence of energy efficiency project implementation for housing stock in Latvia on the construction industry has shown that a definite correlation exists between the amount of investment in the housing stock renovation and the growth of the general indicators of the construction industry and GDP. A more prominent correlation exists between the 
growth of investment and the number of the employed in the industry, while a less prominent correlation is present between investment growth and the growth of average earnings. It is important to stress that data for the period of 12-15 year would allow for higher veracity of analytical calculations. Since investment in the housing stock renovation at large begun in 2010, only data for a period of 7 years (2010-2017) are used for the purpose of this paper. This could have influenced the calculations. However, even this period has demonstrated the accuracy of the assumption that the growth of investment in the housing stock will bring an increase in all the indicators of the construction industry and the economy in general.

\section{References}

AS “Attīstības finansu institūcija Altum” (2016). Daudzdzīvokūu māju energoefektivitātes programma [Energy efficiency programmes for multi-apartment buildings]. Retrieved from https://www.altum.lv/lv/pakalpojumi/energoefektivitate/

Central Statistical Bureau of Latvia. Investment - Key Indicators. Retrieved from http://www.csb.gov.lv/en/statistikas-temas/investment-key-indicators-30533.html

Central Statistical Bureau of Latvia. Wages and Salaries - Key Indicators. Retrieved from http://www.csb.gov.lv/en/statistikas-temas/wages-and-salaries-key-indicators30608.html

Central Statistical Bureau of Latvia. IKG10_01. Iekšzemes kopprodukts pavisam, uz vienu iedzìvotāju un uz vienu nodarbināto [Total GDP, GDP per capita, GDP per employed person] Retrieved from http://data.csb.gov.lv/pxweb/lv/ekfin/ekfin_ikgad_ikp/ IK10_0010.px/table/tableViewLayout2/?rxid=cdcb978c-22b0-416a-aacc-aa650d3e2ce0 (accessed 16.03.2018).

Gassul, V. (2018). Mnogokvartirnij dom: standarti upravlenija i infrastruktura [Multiapartment building: standards for management and infrastructure], 238. Moscow: INFRA.

Golunovs, J. (2014) Energoefektivitāte ēkās [Energy efficiency in buildings]. Retrieved from: http://www.lvif.gov.lv/uploaded_files/sadarbiba/seapplus/National_final_event/Prezenta cijas/Juris_Golunovs_Energoefektivitate_ekas.pdf

LR Ekonomikas Ministrija (2016). Pārskati par pašvaldību palīdzību dzīvokḷa jautājumu risināšanā: 1. pārskats par pašvaldības rīcība esošo dzīvojamo fondu 2016. Gadā [Reviews of the municipal government help in solving the housing problem: $1^{\text {st }}$ review of the municipal government managed housing stock in 2016] Retrieved from: https://www.em.gov.lv/lv/nozares_politika/majokli/petijumi_statistika/

LR Labklājības Ministrija (2011). Gimenes valsts politikas pamatnostādnes 2011. - 2017. gadam [State Family Policy Guidelines 2011-2017], 33-34. Retrieved from www.lm.gov.lv/upload/berns_gimene/lmpamn_200111_gvp

Macih, J. C. (2005). Preventative Maintenance for Multi-Family Housing: For Apartment Communities, Condominium Associations and Town Home Developments. John Wiley \& Sons Inc.

REA vēstnesis No. 29 (2016, Issue 1). Retrieved from http://www.rea.riga.lv/files/ rea_vestnesis/REA_vestnesis_Nr_29.pdf 
Sakovskis, 2018. Implementation of Energy Efficiency Projects in Latvia's Housing Stock and its Influence on the Construction Industry

Sakovskis, A., \& Chekalin, V. (2017/1). Comparative analysis of organization and financing of capital repairs (renovation) in multi-apartment buildings in the cities of Latvia and Russia (cases of Riga and Saint Petersburg). Socialozinatnu vestnesis, 30-46. Retrieved from https://szv.du.lv/lvpublished.html 